\title{
DARWIN'S IRISH CORRESPONDENCE
}

\author{
Miguel DeArce
}

\begin{abstract}
Searches of Darwin's correspondence show that some 160 letters crossed between him and naturalists and others with an Irish address. While few in number, compared to Darwin's 14,000 other known letters, some of this correspondence provoked frequent exchanges between Darwin and his closest collaborators, occasionally leading to amendments to The origin of species or becoming material for Darwin's other publications. The absence of Darwin references in the contemporaneous Proceedings of the Royal Irish Academy or journals of the Royal Dublin Society, where local naturalists published their work, has to be viewed together with the absence in those journals of references to the Irish famines. Other publications of a broader cultural focus engaged both topics in a lively way. Darwin's correspondence was also surveyed for the subject of the island of Ireland, in relation to observations on the distribution of a small group of plants common to Asturias in northern Spain and to the south and west of Ireland, but absent elsewhere in Europe. Patterns of distribution of mitochondrial and Y-specific human DNA markers in western Europe that overlap the distribution of these Asturian plants suggest a common cause for both sets of observations. A modern hypothesis based on these DNA findings is supported by the observations made 150 years ago.
\end{abstract}

Miguel DeArce (email: mdearce@ tcd.ie), Smurfit Institute of Genetics, Trinity College Dublin.

Received 6 June 2007. Accepted 2 April 2008. Published 10 June 2008.

\section{INTRODUCTION}

The reception of Darwin's work among Belfast Presbyterians was studied by Livingstone (1997). The title of Foster's Maynooth lecture, Darwin in Ireland: John Tyndall and the Irish churches (Foster 2002), is geographically more ambitious, but the lecture involves a lag of fifteen years from the first edition of The origin of species (henceforth, The origin) in 1859 to John Tyndall's Belfast Address in 1874 and, concentrating on the Churches' reactions, gives the impression that reaction to Darwin in academic Dublin was lacking. By contrast, in the third edition of The origin (Darwin 1866), Darwin included a Historical Sketch summarising recent progress of opinion on the origin of species and, among other references, mentioning a "Dr. Freke, from Dublin, who already in 1851 had proposed a doctrine of common descent of all living creatures from one primordial form (in The Dublin Medical Press)". We are informed that Dr Freke had published his theory in essay form (Freke 1860), Darwin just remarking that "... the difficult attempt to give any idea of his views would be superfluous on my part". The entry was preserved in future editions (Peckham 1959).

Who read Darwin in Dublin, or who was Dr Freke's intended readership? Was there anything happening in academic Dublin, something perhaps that was less well known than Darwin's work but that had prepared the ground for (or against) Darwin's ideas? Greta Jones (1998; 2004) summarised the early development of anthropology in Ireland in the late nineteenth century, due to Alfred Cort Haddon, as well as the Irish Catholic reactions to Darwin in the early twentieth century and the reactions in middle-class Protestant Belfast and academic Dublin, but she left Darwin's correspondence with academic Dublin largely unexplored.

Here I examine Darwin's massive correspondence for any other clues that could indicate to what extent the intellectual ground in Ireland, including Dublin, either religious or scientific, was receptive or refractory to Darwin's ideas on evolution. This was done in three ways. Firstly, a survey was conducted of the online database of Darwin's correspondence (University of Cambridge 2007), Burkhardt and Smith's 1994 edition of their work $A$ calendar of the correspondence of Charles Darwin, 1821-1882 and any of Darwin's letters published in Cambridge University Press' The Correspondence of Charles Darwin from 1985 to 2007. This survey involved searches for the names of the authors writing for three contemporaneous Irish academic journals and for the names of cities (e.g. Dublin, Belfast) or institutions (e.g. Trinity College, Royal Irish Academy, Royal Dublin Society). Secondly, an attempt was made to capture the mindset of the authors and readers of the said three local academic journals publishing or commenting on the work of Irish naturalists of the time, namely the Proceedings of the Royal Irish Academy, the Transactions of the Royal Dublin Society and The Dublin Review (TDR). These were accessible as complete or nearly complete collections for the period spanning from the publication of the first edition of The origin to Darwin's death in 1882. Although these journals 
were very different in style and content, they were expected, from the viewpoint of their own editorial policies, to deal with aspects of Darwin's evolution by natural selection. A search through Hayes' Sources (1970) was also completed. Thirdly, the question of whether the island of Ireland was for Darwin a subject of natural history studies was considered. In this regard a search was conducted of contemporaneous geological and botanical observations on Ireland made by his correspondents, who would have reported their findings to him. These entries were sought by screening the online correspondence database with the word 'Ireland', filtering out the letters already noticed in the prior searches.

\section{THE 'OFFICIAL' SILENCE OF DUBLIN-BASED NATURALISTS REGARDING DARWIN AND HIS WORK}

A manual search for comments on or reviews of Darwin's work-The origin or any other-in the Proceedings of the Royal Irish Academy, in existence since the late eighteenth century and closely connected with naturalists at Trinity College Dublin, was performed. The keywords 'Darwin', 'evolution' or 'natural selection' did not appear in the title of any of the papers published in the Proceedings during the period 1859-82. Neither was there a book review for any of the six editions of The origin (the Proceedings did not publish book reviews), nor an obituary (the Proceedings did publish obituaries, but they seem to have been strictly local) nor a reference in any of the President's Addresses, where sometimes reference was made to the passing away of outstanding scientists not directly involved with the Royal Irish Academy (RIA).

The only Darwin reference found in the volumes of the Proceedings of the Royal Irish Academy covering that period is a five-word footnote in Hennessy (1870): "See Darwin's Origin of Species p.354." Henry Hennessy (18261901) was an engineer by training, since as a Catholic he was effectively excluded from university education (Falconer 2004). He was librarian at Queen's University Cork and was chosen by Cardinal Newman as professor of physics at the newly established Catholic University of Ireland in 1855, transferring to the Royal College of Science in Dublin as professor of applied mathematics in 1874. He was made a member of the RIA in 1851 and was elected as a Fellow of the Royal Society (FRS) in 1858. Although not a botanist, he commented on the origin of the south European plants found growing in the west and south of Ireland, a topic that will be discussed later in this paper.
With regard to the journals produced by the Royal Dublin Society (RDS), a careful examination of Mollan's index (1987) revealed a similar absence of papers with titles bearing any of the relevant keywords. There is some overlapping of authors in the RIA and RDS publications.

Such absences, however, should not be taken as an indication that Irish naturalists, who published their work through the Proceedings of the Royal Irish Academy or the Proceedings of the Royal Dublin Society, were ignorant of Darwin's work. The minutes of the RIA (Anonymous 1864) inform us that Darwin, together with $\mathrm{R}$. Clausius and Michael Chasles, was elected as an Honorary Member of the RIA at the first meeting presided by Lord Talbot of Malahide in 1864, although the journal is not explicit as to the reasons for their election, or to who on the Committee of Science proposed or seconded the names. Members of the RIA's Committee of Science for that year were Robert W. Smith, MD; Robert McDonnell, MD; William K. Sullivan, PhD; Joseph B. Jukes, MA; George Johnstone Stoney, LLD; Rev. George Salmon, DD; and James Apjohn, MD. Several of these had had correspondence with Darwin before 1859. In many cases there were mutual debts for large or small professional favours. Edward Percival Wright, professor of zoology at Trinity College Dublin, also had administrative correspondence with Darwin, in 1865 and 1879.

Robert McDonnell and Joseph Beete Jukes had corresponded with Darwin on issues of a more technical nature, the latter in 1838, seeking advice about getting a government appointment to do the Geological Survey of Newfoundland-an appointment that he eventually did get, in the absence of competition, as informed by Darwin on 25 December 1838 (Burkhardt and Smith 1986). In total there are nine letters extant between the two men, four of which were written by Darwin. However, Jukes is mentioned by Darwin another 40 times in his correspondence with Joseph D. Hooker, Charles Lyell, Thomas H. Huxley and others, Darwin always speaking highly of him. By 1862, twenty-four years after his appointment to the Geological Survey of Newfoundland (Burkhardt et al. 1997), Jukes still corresponded with Darwin on geological and other matters. One of the questions under scrutiny then was the rate of erosion at the top of higher areas of the Weald, an anticline or dome structure made mostly of soft sedimentary rock and running from the east of Hampshire to the east of Sussex and Kent, extending for about $135 \mathrm{~km}$ from east to west and $50 \mathrm{~km}$ from north to south. In the first edition of The origin (Darwin 1859) Darwin had estimated a rate of denudation of sedimentary rock deposits of one inch per century, thus, requiring 306,662,400 years for the current exposure of the Weald area. 


\section{DARwin's Irish CORRESPONDENCE}

This estimate was halved in the second edition and completely removed from the third edition onwards (for all editions, see Peckham 1959). However, from his observations on denudation rates by rivers in Ireland, Jukes (1862) did not think the remark should be withdrawn, adding the following in a letter to Darwin (Burkhardt et al. 1997):

Supposing my explanation be right in Ireland it must be applicable elsewhere. The Weald for instance, which after all is a mere flea bite compared to the denudation of the Palæozoic rocks. - I suspect that the Chalk was bared of the Tertiary rocks by marine denudation as the rock rose above the Sea, that brooks commenced to run down the chalk slopes along the courses of those which now cut ravines through the Chalk escarpments, \& that those ravines have been worn by those brooks continually cutting deeper than the ground inside, that the Chalk which has been removed has been merely dissolved off the crown of the arch by atmospheric action \& the hills \& valleys inside worn by the rain only \& the weather. Your 300,000,000 of years is not nearly enough for the denudation of the Weald by this process.

At the time, Jukes was director of the Irish branch of the Geological Survey. Darwin always regarded Jukes as a sympathetic supporter and dedicated to him a copy of his book on orchids. However, the paragraph deleted in the third edition of The origin was never restored. But Jukes' observations were not always on geological matters. On 3 November 1862, Jukes advised Darwin on a simpler matter, more easily observed (Burkhardt et al. 1997):

You know of course how the inaccuracy of some little trifling incidental statement in a book reflects its authority in the minds of some people who never take the trouble to compare the crooked grain of sand with the symmetrical mountain.

I heard your Origin of Species laughed at the other day because you assume that the young bird pecks its way out of the shell with its own beak.- Certainly this seems to me an impossibility looking at the way in wh. the young bird is coiled up in the shell with its beak almost under its wing (see for instance the plate in Rymer Jones Outlines An: Kingd)

-Others present supposed that the old bird broke the egg for the young one to come out, \& my wife tells me that that was the way all the old henwives told her it was done.-

Your critic however said that on applying to an old woman on the point she laughed at him and said "why Lord bless you, Sir, the young un' grows too big for the shell \& busts it" \& that does seem to me the most reasonable supposition-

Your statement at p $87 \mathrm{wd}$. therefore either need revision or the facts on which it is based verification.-
However, the statement remained unchanged in all further editions. Curiously, Darwin did not comment of having actually observed the hatching of a chicken, and neither did Jukes, both being content with quoting second hand.

Robert McDonnell's work on the electrical organs of fishes was known to Darwin (Burkhardt et al. 1993) from an initial letter that McDonnell had sent him. First personal impressions, written in a letter to Huxley on 16 November 1860 (Burkhardt et al. 1993), were not good: "I wonder whether he is the bearded man one sees at B. Assoc ${ }^{\mathrm{n}}$. If so I fear he is rash \& wild." Huxley put him right, explaining that Darwin was confusing Robert McDonnell, the Dublin co-editor of the Natural History Review, with John Denis MacDonald, the naval surgeon and microscopist. Darwin's first impression changed quickly on receipt of a second letter (Burkhardt et al. 1993): "I have had a second, such a capital, letter from him. He will in time come round to our view on Species as I believe." Neither of McDonnell's letters to Darwin has been found. Darwin was, however, very pleased with McDonnell's comments on his work, as he explained to Lyell later (Burkhardt et al. 1993):

P.S. I must tell you one little fact which has pleased me. You may remember that I adduce Electrical Organs of Fish, as one of the greatest difficulties which had occurred to me, \& Owen notices the passage in a singularly disingenous [sic] spirit. Well Mc.Donnell of Dublin (first rate man) writes to me that he felt the difficulty of whole case as overwhelming against me. Not only are the fishes which have electric organs very remote in scale; but the organ is near Head in some \& near tail in others \& supplied by wholly different nerves.- It seems impossible that there could be any transition.

Some friend who is much opposed to me seems to have crowed over Mc.Donnell, who reports that he said to himself that if Darwin is right there must be homologous organs both near the Head \& Tail in other non-electric fish. He set to work \& by Jove he has found them. So that some of difficulty is removed, $\&$ is it not satisfactory that my hypothetical notions shd have lead to pretty discovery. Mc.Donnell seems very cautious; he says years must pass before he will venture to call himself a believer in my doctrine; but that on the subjects which he knows well viz morphology \& embryology my views accord well \& throw light on whole subject.-

Peckham's variorum edition (1959) shows that Darwin redrafted the paragraph on electric organs of fish no less than fourteen times, partly under the influence of McDonnell's findings.

Among the RIA naturalists, the most common concern was the systematics and descriptive anatomy of plants and animals, which comprised 
the background needed to appreciate Darwin's new ideas, especially the idea of variation. William Henry Harvey, born in Summerville, Limerick, in 1811 to a large Quaker family, was professor of botany at Trinity College Dublin for the period 1856-1866. He was also keeper of the herbarium at Trinity, and he had worked formerly at the Royal Dublin Society and the botanic gardens at Glasnevin. A biography of Harvey can be found in Nelson (2004), with references therein, and his impressive botanical bibliography appears in Nelson and Parnell (2002). For the period from 1844 to Harvey's death in 1866, the online database of Darwin's correspondence (University of Cambridge 2007) mentions 95 letters that passed between him and Darwin, or between Darwin and others where Harvey's work is mentioned, respectful of his authority as a botanist except in those occasions where Harvey was carried away by his sense of humour and was not respectful with himself or with Darwin (Nelson 2004). Of the 95 letters, only eight are from Harvey to Darwin, but some are unusually long. The second letter (Burkhardt et al. 1993) is 5,812 words long, and Darwin appended two lengthy notes sketching a reply. While we only have two letters from Darwin to Harvey (Burkhardt and Smith 1988), it is obvious from the correspondence that several more were written and are now missing. From the late 1830 s, Harvey was also a good friend of the Hooker family and a frequent visitor at Kew (Burkhardt and Smith 1987), and Hooker reciprocated by visiting Harvey in Dublin, where he heard a performance of the Messiah (Burkhardt and Smith 1989). With Hooker, Harvey visited the Darwins at Down from 28 to 31 August 1858 (Burkhardt and Smith 1991). Harvey was a world expert in algae, and he contributed to the discovery that algae reproduce sexually (Burkhardt and Smith 1990). However, the publication of The origin put some strain on the personal relationship between him and Darwin. Harvey felt at liberty to criticise The origin using his own arguments, and he gave a lecture on Darwinism to the Dublin University Zoological and Botanical Association on 17 February 1860 (Nelson 2004), where he was jocose. Darwin took this reasonably lightly, telling Hooker (Burkhardt et al. 1993):

I return Harvey's letter: I have been very glad to see the reason why he has not read your Essay, I feared it was bigotry. And I am glad to see that he goes a little way (very much further than I supposed) with us on Nat. Selection.- I was not sorry for a natural opportunity of writing just to show that I was not piqued at his turning me \& my book into ridicule,not that I think it was proceeding which I deserved or worthy of him.-
After the event, Harvey had been suitably apologetic (Nelson 2004). But his criticisms were made explicit in his long letter dated 24 August 1860 (Burkhardt et al. 1993). For instance, in the first edition of The origin Darwin says (1859):

\begin{abstract}
In North America the black bear was seen by Hearne swimming for hours with widely open mouth, thus catching, like a whale, insects in the water. Even in so extreme a case as this, if the supply of insects were constant, and if better adapted competitors did not already exist in the country, I can see no difficulty in a race of bears being rendered, by natural selection, more and more aquatic in their structure and habits, with larger and larger mouths, till a creature was produced as monstrous as a whale.
\end{abstract}

In his letter of 24 August 1860 Harvey commented on this point:

... I find that particular instances, intended to illustrate how Natural Selection has acted or might be supposed to act in certain cases, almost always incline me to withdraw my assent to the previous argument. ... when-following your argument-I am half inclined to admit the successive development of species from species, I come to your Illustrations, instead of my faith in my teacher being confirmed, I am absolutely repelled, \& forced to suspect some undetected flaw in his line of reasoning. For instance, the speculation on the bear \& the whale, of which I dare say you have heard enough, simply made me laugh.

Darwin removed the paragraph from the second edition onwards, although he later regretted it (Burkhardt et al. 1994). In a similar vein in the first edition (Darwin 1859) Darwin had argued the following:

... islands often possess trees or bushes belonging to
orders which elsewhere include only herbaceous
species; now trees, as Alph. de Candolle has shown,
generally have, whatever the cause may be, confined
ranges. Hence trees would be little likely to reach
distant oceanic islands; and an herbaceous plant,
though it would have no chance of successfully
competing in stature with a fully developed tree,
when established on an island and having to compete
with herbaceous plants alone, might readily gain an
advantage by growing taller and taller and
overtopping the other plants. If so, natural selection
would often tend to add to the stature of herbaceous
plants when growing on an island, to whatever order
they belonged, and thus convert them first into
bushes and ultimately into trees.

In his comment on this passage Harvey (Burkhardt et al. 1993) drew from his vast direct knowledge of the South African and Pacific flora, where he found the only arborescent Compositae, 


\section{DARWIN'S IRISH CORRESPONDENCE}

an order that is otherwise made of herbaceous plants. And in Tasmania, the most arborescent of the Compositae, Eurybia argophylla, grows not among grasses and bushes, but under much bigger Eucalyptus.

Darwin struggled with this paragraph in the fourth, fifth and sixth editions (Peckham 1959), eventually fixing it as follows (Darwin 1872):

... an herbaceous plant, which had no chance of successfully competing with the many fully developed trees growing on a continent, might, when established on an island, gain an advantage over other herbaceous plants by growing taller and taller and overtopping them.

Within one month of receiving Harvey's long letter, Darwin wrote a very comprehensive private response, where he said (Burkhardt et al. 1993):

Parts of your letter seem to me, if I may be permitted to say so, very acute \& original; \& I feel it a great compliment your giving up so much time to my book. But on the whole I am disappointed ... because it seems to me that you do not understand what I mean by Natural Selection, as shown at p. 11 of your letter \& by several of your remarks. - As my book has failed to explain my meaning it would be hopeless to attempt it in a letter. You speak in early part of your letter \& at p. 9. as if I had said that Natural Selection was the sole agency of modification; whereas I have over \& over again, ad nauseam, directly said \& by order of precedence implied (what seems to me obvious) that selection can do nothing without previous variability. see p. 80 , 108, 127, 468, 469 \&c "Nothing can be effected unless favourable variations occur". I consider Natural Selection as of such high importance, because it accumulates successive variations in any profitable direction; \& thus adapts each new being to its complex conditions of life.- The term "Selection" I see deceives many persons; though I see no more reason why it should than elective affinity, as used by the old chemists. If I had to rewrite my book, I would use "natural preservation" or "naturally preserved". I shd. think you would as soon take an emetic as reread any part of my Book, but if you did \& were to erase selection $\&$ selected $\&$ insert preservation \& preserved, possibly the subject would be clearer.

Harvey was one of many naturalists opposed to natural selection as the vera causa for the origin of species. He also argued against the idea of speciation being an infinitesimally slow process (Burkhardt et al. 1993), giving the example of Begonia frigida, in which it appeared that a new species had originated through the abnormal development of the existing form. If this proved to be the case, he stated, Darwin's "theory would receive a serious damage" (ibid.). On 23 February 1860, Darwin (Burkhardt et al. 1993) commented to Lyell:
Hooker is going to answer Harvey (ie if Lindley will admit) \& I am very glad of it; - you can see answer, when (as I am delighted to think) you will be here. Aspicarpa is a most interesting case, like the difference, on which I have enlarged a little, of difference in most important characters in the outer \& inner florets of Compositous \& Umbelliferous plants.- I think these facts are most important as showing how easily what naturalists call very important characters may be modified by correlation of growth. But I doubt whether they throw light on abrupt origin of new forms. At least I have tried long \& hard with respect to such cases as Aspicarpa; \& I could find only one apparent case in the Campanulaceæ. - With respect to animals, besides the case of monstrous Gold-fish with analogous fish in state of nature alluded to, I have wondrous case of monstrous eels, (examined by Agassiz) \& apparently produced by darkness, but I cannot satisfy myself on case; nor does it appear certain that they breed.- On the whole I still feel excessively doubtful whether such abrupt changes have more than very rarely taken place.-

Years later, Harvey (Burkhardt et al. 2001) would present Darwin with another case of apparent speciation occurring in one step in the dandelion. In his opinion the difference between the normal dandelion and a new dandelion that he had found while on a field class with his students was enough to classify them not just as different species but as different genera! Darwin was indeed interested in the case, and he mentioned it repeatedly to Hooker, encouraging Harvey to publish the case.

In spite of these misunderstandings, through their mutual friend Hooker, Harvey and Darwin continued to cooperate, Harvey providing Darwin with useful information for his orchid book and for his book on climbing plants. Harvey's private obituary, sent to Darwin by Hooker (Burkhardt, in press), is a warm tribute:

Harvey is gone, he died last Tuesday after much suffering at last, attended by his wife and my Mother and Sister, to whom he had long been as a son \& brother, I shall never see his like again:-for purity of Spirit and sweetness of Temper he was equalled only by Henslow; but then he had beside an exquisite sensibility of temperament \& extreme delicacy of feeling that in other people are combined with irritability or vanity. A more unassuming or unselfish man never lived, \& when I think how much purer \& better he was than I am I smite my self reproaching conscience \& feel stricken with shame \& sorrow, almost with remorse. He will be buried at Torquay on Saturday, but it will be utterly impossible for me to go to the funeral. His loss to Science will be very great. He was a good most painstaking \& most conscientious working Botanist, \& he leaves no successor fit for his Chair or Herbarium studies. I do not know how it is, but the demand for systematic Botany is enormously greater than for any other 
branch of Nat. Hist. Science of a practical sort I mean - \& all Harvey's works were useful \& good.-

Alexander Goodman More (1830-1895) was co-author, with David Moore, of Cybele Hibernica (published by subscription from 1866), having published several more localised surveys of Irish plants. His zoological work concentrated mostly on birds. He was curator of the Dublin Natural History Museum from 1867 to 1881 . The current database of the Darwin Correspondence Project (University of Cambridge 2007) mentions nine letters exchanged between More and Darwin in the 1860s, mostly concerning the bee orchidinformation requested by Darwin while he was preparing his book on orchids, published in 1862 and 1877. More's contribution to this work is acknowledged five times in the text (Darwin 1877). These letters illustrated Darwin's frequent modus operandi, doing experiments and making observations by reliable proxies. Another correspondent was Robert Ball (1802-1855), president of the Geological Society of Ireland and director of the museum at Trinity College Dublin. George James Allman, professor of botany at Trinity College from 1844 to 1856, was a latecomer as a Darwin correspondent, as his first letter was dated 1871. The few letters exchanged were mostly on administrative matters.

Samuel Haughton (1821-1897) (Spearman 2004) was professor of geology at Dublin University from 1851 to 1881 and came to be regarded by Darwin as a "bitter opponent" (Burkhardt et al. 1994). He became President of the RIA in 1886 and had a leading role in the reform of the curriculum at the medical school in Trinity. Haughton was the first Darwin critic in Ireland, and Darwin himself mentions him in his autobiography (Darwin 1958) as the first to mention his and Wallace's joint paper published in 1858. This became a fuller and very negative review of The origin in 1860 (Haughton 1860). In the initial days after the publication of The origin Darwin delighted in collecting opinions about his book, but Haughton was "too coarse, too horrid" (Burkhardt et al. 1993), and Darwin was deeply hurt. In a letter to Lyell Darwin said (ibid.):

Did you read Haughton in Dublin Mag. of Nat. Hist. $\mathrm{He}$ is more coarsely contemptuous than even $\mathrm{Mr}$ Dunns in N. British \& overdoes everyone else in misrepresentation. I never knew anything so unfair as his ignoring in his remarks on Bee's cells the almost exactly intermediate comb of Melipona; \& so in many other cases. It consoles me that he sneers at Malthus, for that clearly shows, mathematician though he may be, he cannot understand common reasoning. By the way what a discouraging example Malthus is to show during what long years the plainest case may be misrepresented \& misunderstood.
David Moore was curator of the Royal Dublin Society's botanic gardens at Glasnevin throughout the period of the potato blight in the 1840s, and he contributed to the establishment of the pathogenic effect of Phytophthora (Nelson 1995; Nelson and Seaward 1980). Moore kept a constant interest in the subject, corresponding with Darwin on potato issues in 1874 and 1879. It is interesting that Darwin, who at this time (1879) was corresponding with James Torbitt on the same topic of potatoes, apparently did not put the two men in contact, deciding to help Torbitt (even financially, see below) while turning Moore down. Moore published extensively in systematic botany; for instance, on mosses (Moore 1870) and Hepaticae (1876). Moore had his own opinions on evolution but kept them to himself while corresponding with Darwin on less controversial matters. In his 1875 lecture, Design in the structure and fertilization in plants, a proof of the existence of God (Moore 1875), written as a reaction to John Tyndall's famous Belfast Address of 1874, Moore revealed himself as an excellent observer and teacher and as a religious believer who did not feel in any way disqualified to do science. He clearly saw the divine plan in the newly found detail of the structure and function of flowers, with their innumerable adaptations.

\section{THE ENTERPRISING GROCER AND THE CAREFUL LOBBYIST}

Not all of Darwin's correspondents were naturalists, and this holds true also for his Irish correspondents. It is worth mentioning here that undoubtedly the most prolific of Darwin's correspondents from the whole of Ireland was not an academic but a grocer and wine merchant from Belfast, a Mr James Torbitt (DeArce in press). Both men exchanged 93 letters between January 1876 and January 1882, and another 50 letters crossed between Darwin and his closer collaborators or acquaintances asking for advice or help for Torbitt's scheme. Torbitt had first asked Darwin that if a potato is constantly reproduced from the tuber, and not the true seed, are we then always dealing with the same individual, therefore, with a very old one, which would be weakened and more susceptible to the potato disease than the younger plants that grow directly from true seed. This was not a new idea, as it had been reviewed by Moore fourteen years earlier (Moore 1860). The argument for growing potatoes from seed rather than from the tuber ad infinitum was proposed by Torbitt before the British Association for the Advancement of Science meeting in Belfast in 1874 and was reported in The Times (Anonymous 1874). The reporter informs us that a Mr Carruthers, from the British Museum, completely opposed Torbitt's idea. Carruthers was 
in a powerful position and hindered both Moore and Torbitt in their potato research.

Although in his private capacity Darwin was able to raise for Torbitt nearly $£ 500$ over three years from friends and relatives, his lobbying failed to attract business from the government, which purchased from the blight-resistant cultivars developed by Scottish growers, who operated in a much larger scale. Torbitt and Darwin's attitudes with regard to the failure of the potato in Ireland contrast with those of most Irish scientists at the RIA, except David Moore, who was frustrated, like Torbitt, by a chronic lack of money for his potato research at Glasnevin (Nelson 1995). Torbitt's methodology to solve the problem makes him possibly the first applied hybridist in Ireland, but he was only relatively successful.

Another interesting non-naturalist correspondent was William Graham, professor of political economy at Belfast (1882-1909), who corresponded with Darwin (nine letters in total, starting in 1881) seeking an opinion on his book Creed of Science, written in 1881. Darwin, ever polite, praises the book but disagrees that the existence of natural laws implies purpose, stating his "inmost conviction" that "the Universe is not the result of chance" (Burkhardt et al. 1994). But then he was assaulted by a "horrid doubt whether convictions of man's mind, which has been developed from lower animals, are at all trustworthy" (ibid.).

\section{DISCUSSION: SCIENTISTS' ATTITUDES TO DARWIN IN ACADEMIC DUBLIN}

In the 1850 s both the Proceedings of the Royal Irish Academy and TDR were journals of mixed contents, covering to some extent the sciences and the humanities. But while the Proceedings included three committees - antiquities; polite literature; and science, including anatomy, astronomy, descriptive botany and zoology, mathematics (Sir W.R. Hamilton published here regularly), geology, meteorology, physics and physiology - TDR was a review of books targeted to a more religiously specified readership, i.e. the educated Irish Catholic, lay or (mostly) clerical. Papers in TDR were anonymous, and they included lengthy reviews on current religious publications; papal documents; parliamentary politics as it affected Ireland, especially education politics and the role of universities; the role of Catholic intellectuals in Irish society; and other topics. Darwin and Darwinism did feature prominently in TDR of the second half of the nineteenth century, not so much as a scientific subject but as a subject of theological debate. A review of The origin duly appeared (Anonymous 1860), and several comments followed, some of them penned by St George Jackson Mivart-a Catholic convert who rejected natural selection as the main mechanism of evolution - and, towards the end of the century, by Bishop Hedley - a Catholic bishop who was quite sympathetic to the idea of human evolution as long as the initial creation was safeguarded. John Henry Newman, the founder of the short-lived Catholic University in Ireland, one of whose publications was TDR, supported the nomination of Darwin for an honorary degree at Oxford in spite of opposition labelling him as anti-christian. Newman had said that "... [Darwin] deserves a degree as much as many others, who have one" (Roberts 2007). In the end Darwin declined the honour on the grounds that he could not stand the strain of the ceremony (Burkhardt et al. 1994).

The editors of the Proceedings of the Royal Irish Academy did not engage publicly with Darwin or the topic of evolution, and this may have been because they considered this debate was taking place elsewhere; for instance, in the Dublin University Magazine, TDR and other journals of broader cultural interest (see Hayes 1970). In addition it can be considered that science in Ireland then was an activity restricted to the ascendancy. Attis (1997) has commented on the social context of Irish science at the time of Hamilton's conical diffraction papers, in the Dublin of the 1830s. Hamilton wanted to break the spell of Trinity as the 'silent sister', putting Ireland on the intellectual map of the UK and Europe. Perhaps this relative silence about Darwin in scientific circles was also a characteristically Irish reaction of a different sign: they may not have wanted to put Trinity on the map as too reactionary to science. Irish scholars, and those at Trinity College in particular, whether approving or not, did know Darwin and his work very well and had contributed to it or suggested alterations in a way that Darwin took seriously and appreciated, but they felt there was something about evolution that went beyond science. Darwinism cut the Irish academic community in many ways, and bitter arguments between Church of Ireland and Presbyterian, Protestant and Catholic, idealist and utilitarian, atheist and believer, selectionist and Lamarkian, and ascendancy and democracy were never too far away in a small island so divided, in a small city that imposed close proximity. The presumably heated discussions with an entrenched opponent could be uncomfortable and unsightly for academics who had to share the same campus. Peaceful coexistence was a more practical attitude than the war of words that followed Darwin elsewhere, as was the case of Belfast after Tyndall. It was not fear of debate that kept many of these Irish academics quiet on this subject, as can be seen by their debates on matters of science, but the 
religious aspect of the subject. Living in a mixed community, keeping religion ostensibly separate from science, especially when science was one's own 'workplace', had advantages.

Speaking of A.R. Wallace, Rosen (2007) describes how science was the realm of the superior class, a class privilege, an exciting mind game to play with friends, an expensive hobby for the wealthy, but of little consequence to the ordinary folk. To make a name as a naturalist at that time required extensive travel, often in conditions of wilful hardship, which was only available to the rich.

The Proceedings of the Royal Irish Academy did not publish debate on or mingle with current affairs that really affected people's daily lives. This is clearly indicated by the fact that it barely dedicated two lines to a natural phenomenon of such dramatic consequence as the successive failures of the potato crop in Ireland from the 1840s to the 1890s, while it described in detail many other more impersonal and abstract natural phenomena of the day. The only reference in the Proceedings to the potato problem occurred in 1848 (Anonymous 1848), where His Grace, the Archbishop of Dublin, reported that "immersion in warm tar is an effective preservative against the potatoe disease". Moore's practical interest in the subject found its readership elsewhere, namely in the Proceedings of the Royal Dublin Society in 1846, 1847 and 1860, but even here he was the sole voice. TDR, as was its brief, followed events closely, but vicariously, through reports in other publications. For instance, volume 34 includes a review (Anonymous 1852) of Francis B. Head's $A$ Fortnight in Ireland, which turns out to be a cruel and unsympathetic account of the dire effects of the famines, and volume 104 contains a commentary (Anonymous 1863) on the Census of Ireland for 1861, 1851 and 1841, illustrating the effect of the famine on population and landscape.

In any case the personal biases of its scholars, as seen in their publications, did not reflect the institutional position of Trinity College towards Darwin. The Times of 26 June 1886 (Anonymous 1886) reports on the conferring of an honorary degree to John Tyndall at a ceremony where, unusually, there was opposition from the floor. Darwin was a divisive issue.

\section{THE ISLAND OF IRELAND AS A SUBJECT OF NATURAL HISTORY STUDIES IN DARWIN'S CORRESPONDENCE}

Surveying Darwin's correspondence with Irish naturalists revealed that the topic of Ireland as a subject for natural history studies came up repeatedly prior to the first edition of The origin.
Islands were, after all, privileged ground for the study of evolution, and this one island was quite obvious to him. Darwin's interest in Ireland was due to Edward Forbes (1815-1854), a brilliant young man for whose intellect Darwin felt the utmost respect. Forbes, born in Douglas, Isle of Man, had been the resident naturalist on board HMS Beacon from 1841 to 1842 . His career was as meteoric as it was short. On the year of his return, he was appointed as professor of botany at King's College, London, and as curator of the museum of the Geological Society of London. He was a palaeontologist with the Geological Survey of Great Britain in the period 1844-54, he became professor of natural history at Edinburgh University in 1854, and he was appointed as a FRS at the age of 39. Edward Forbes features prominently in The origin, being quoted 15 times.

Forbes travelled extensively across Europe and published many essays on geology, including his early On the connection between the distribution of the existing fauna and flora of the British Isles, and the geological changes which have affected their area, especially during the epoch of the Northern Drift. The entry on Forbes in Encyclopædia Britannica tells us the following of this essay (Encyclopædia Britannica 2007):

It is therein pointed out that, in accordance with the theory of their origin from various specific centres, the plants of Great Britain may be divided into five well-marked groups: the W and SW Irish, represented in the $\mathrm{N}$ of Spain; the SE Irish and SW English, related to the flora of the Channel Islands and the neighboring part of France; the SE English, characterized by species occurring on the opposite French coast; a group peculiar to mountain summits, Scandinavian in type; and, lastly, a general or Germanic flora. From a variety of arguments the conclusion is drawn that the greater part of the terrestrial animals and flowering plants of the British Islands migrated thitherward, over continuous land, at three distinct periods, before, during and after the glacial epoch.

Chronologically, Darwin mentioned Forbes to his wife, Emma, as the best choice of editor for his work, after Lyell himself (Burkhardt and Smith 1987). An initial series of letters was exchanged between the two men when Darwin asked Forbes if he could work out the depth of an ancient sea from the nature and type of fossil shells found today. Forbes said that, with some reservations, he could, as shells from deeper deposits are smaller in size than those deposited higher up. Then early in 1846 (Burkhardt and Smith 1987), Forbes explained to Darwin his theories on the colonisation of south-west Ireland by plants from northern Spain:

My Cambridge argument was this - that no known currents whether of water or air, or ordinary means of 


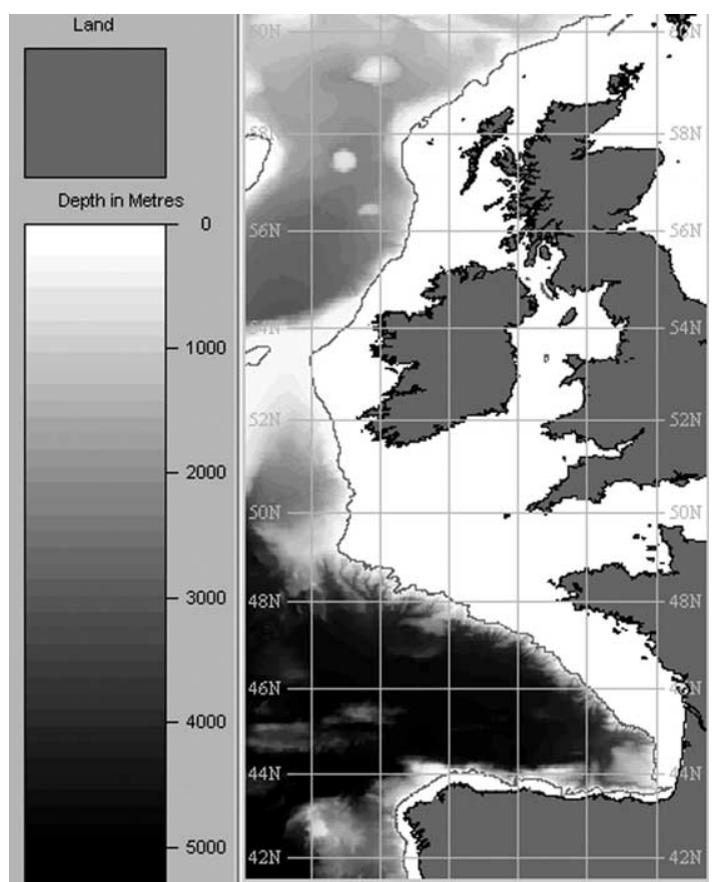

Fig. 1-Bathymetry of the Bay of Biscay, showing Ireland and Britain engulfed by the continent at depths of about $130 \mathrm{~m}$ (100 fathoms is approximately $600 \mathrm{ft}$ or $182 \mathrm{~m})$. Image obtained using the GEBCO One Minute Grid (International Oceanographic Commission et al. 2003). The band of pure white colour adjacent to land and the continuous thin line close to the periphery indicate the $130 \mathrm{~m}$-depth contour line.

transport would account for the little group of Asturian plants- $\mathrm{few}$ as to species but playing a conspicuous part in the vegetation-giving a peculiar botanical character to the South of Ireland. That as I had produced evidence of the other floras of our Islands (i.e. the Germanic - the Cretaceous \& the Devonian (these terms used topographically not geologically) having been acquired by migration over continuous land (the glacial or alpine flora I except for the present - as ice-carriage might have played a great part in its introduction)) I considered it most probable \& maintained that the introduction of that Irish flora was also effected by the same means. I held also that the character of this flora was more southern \& more ancient than that of any of the others, - \& that its fragmentary \& limited state was probably due to the plants composing it having (from their comparative hardiness - heaths, Saxifrages \&c) survived the destroying influence of the glacial epoch.

My geological argument now is as follows: Half the Mediterranean Islands or more are partly-in some cases (as Malta) wholly-composed of the upheaved bed of the Miocene sea: so is a great part of the south of France from Bourdeaux to Montpellier: so is the west of Portugal, \& we find the same corresponding beds with the same fossils (Pecten latissimus \&c) in the Azores. So general an upheaval seems to me to indicate the former existence of a great post-Miocene land, the region of what is usually called the

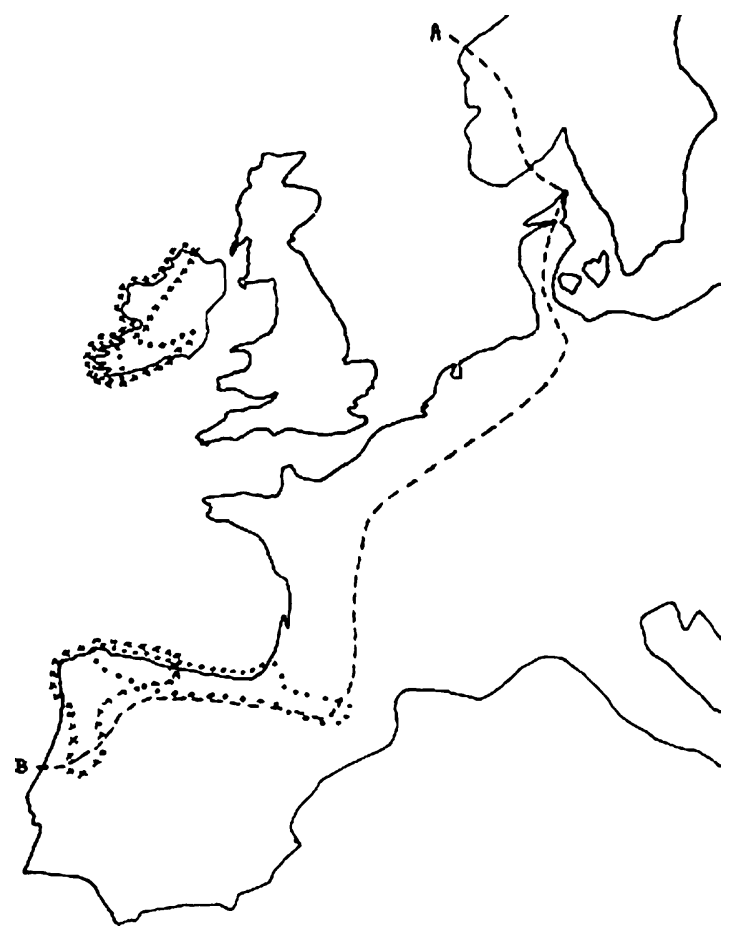

Fig. 2-Western Europe, showing the limits of the strictly Atlantic region (defined by the line $\mathrm{AB}$ ) and the continental distribution of two Atlantic species found in Ireland but not in Britain-Saxifraga hirsuta and Saxifraga spathularis. Image taken from Webb (1983).

Mediterranean flora. (Every where these Miocene islands \&c bear a flora of that type) If this land existed it did not extend to America (for the fossils of the Miocene of America are representative \& not identical): where then was the edge or coastline of it, Atlantic-wards?

Darwin was reluctant to accept, as Forbes proposed, that Europe had once extended as far as the Azores. Darwin continued to search for other means of plant dispersal, in particular the possibility that sea currents could have transported viable seeds from Asturias in northern Spain to Ireland. $\mathrm{He}$ published his results in the Gardener's Chronicle of 21 May 1855 (Burkhardt and Smith 1989). He tried to germinate 23 types of seeds, which had been immersed in salty water outdoors for several days to several weeks, with or without snow added. $\mathrm{He}$ observed that the legumes died soon enough and did not germinate, but the seeds from most of the other genera did survive. He felt that, considering an average rate of progress of 33 nautical miles per day, these seeds could travel between 1,300 and 1,400 miles in viable condition in a period of six or eight weeks. The fact that the seeds sank to the bottom of Darwin's jars was not taken as an insurmountable problem, Darwin suggesting that perhaps uprooted plants or fruits could have been dragged by the currents. 


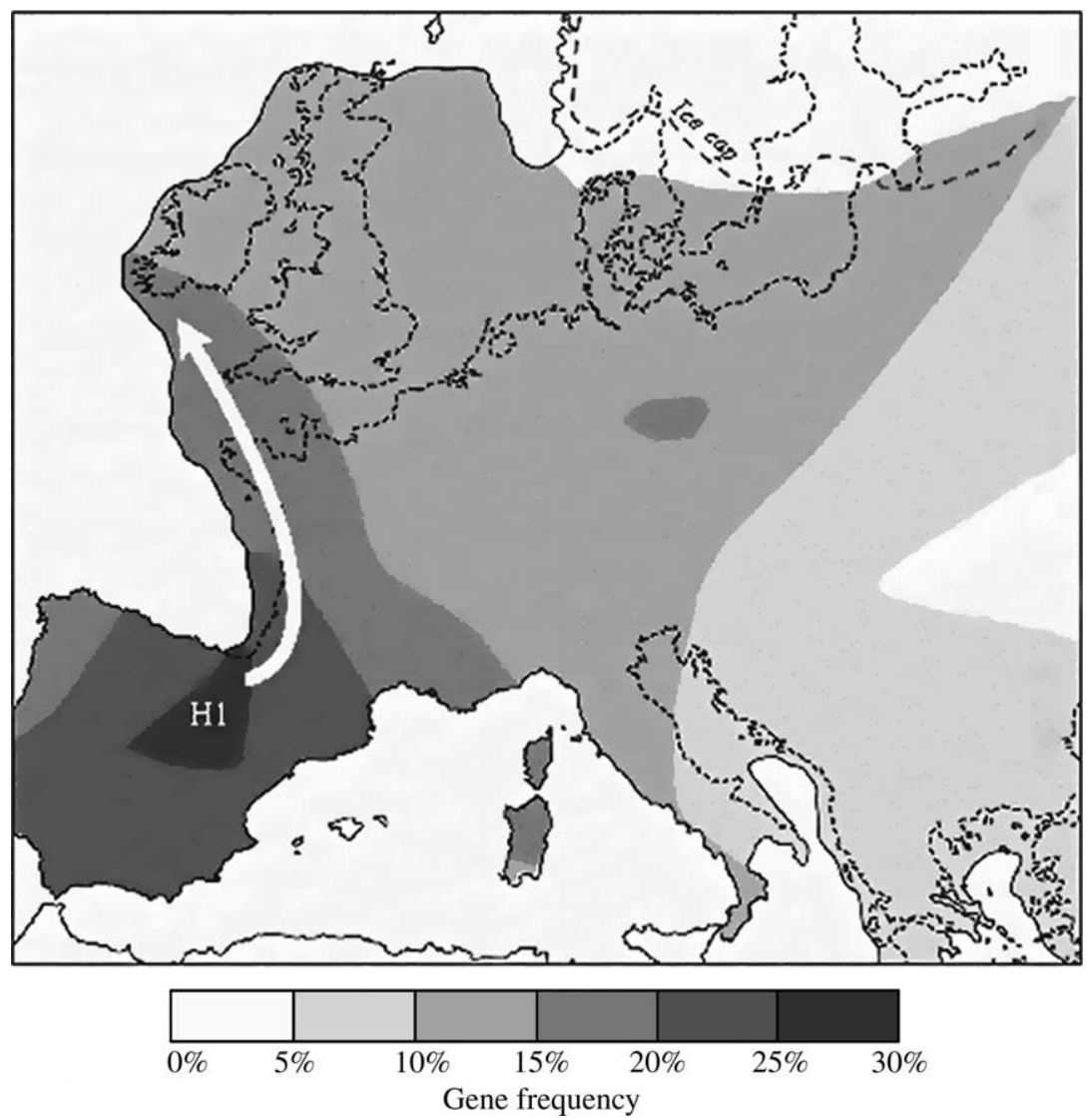

Fig. 3-The immediate impact of material re-expansion into north-west Europe from Iberia after the Ice Age from 15,000 years ago. Contour map of $\mathrm{H} 1$ (Helina main sub-group) gene frequency-arrow indicates direction of gene flow based on the gene tree and geography. Contours follow greater land area resulting from low sea level and avoid the ice cap (Scandinavia excluded from analysis). Compare with Fig. 2. Helina is obtained from mitochondrial DNA. Map and caption reproduced with permission from Oppenheimer (2006).

By 1868 , Darwin had read Hennessy's remarks on the origin of the south European plants found growing in the west and south of Ireland (abstracted in Hennessy 1870). Hennessy observed that the isothermal lines of mean annual temperatures of $52^{\circ}$ and $51^{\circ} \mathrm{F}$ and mean winter temperatures of $45^{\circ}$ and $44^{\circ} \mathrm{F}$ outlined precisely the Irish 'Asturian' region, being identical with the corresponding isothermal lines in Asturias. Although the summer isothermal lines that occur in Spain do not occur anywhere in Ireland, this was interpreted as a mechanism for selection in Ireland against the Asturian plants requiring hotter summers. In summary Hennessy put forward the following propositions to explain the distribution (Hennessy 1870):

During two periods of prolonged and intimate intercourse between the northern coast of Spain and the whole of Ireland, the conditions for bringing the seeds of various Plants into the latter country from the former probably existed; and during the more recent of these periods, the existence of such trading and fishing intercourse between Spain and the Asturian districts of Ireland is so well established, and was of such kind as to render the introduction of accidental seeds almost certain.

The author [Hennessy] briefly discussed the grounds which we possess for believing in a former intercourse between Spain and Ireland at a very remote epoch; and he examines, with great minuteness and detail, the evidence of such intercourse during a more modern period. It appears that from the thirteenth to the sixteenth centuries, inclusive, the west and South-West of Ireland were in close communication with the ports of Biscay and the Asturias. Local histories and traditions, popular poetry and unpublished documents were referred to in support of this conclusion ...

So Hennessy was proposing human migration as the cause of the peculiar distribution of these plants. But perhaps the most telling letter in this connection came from Lyell to Darwin in late 1860 (Burkhardt et al. 1993):

... you will see that a low plain of land skirting the Bay of Biscay \& France \& joining Ireland would 


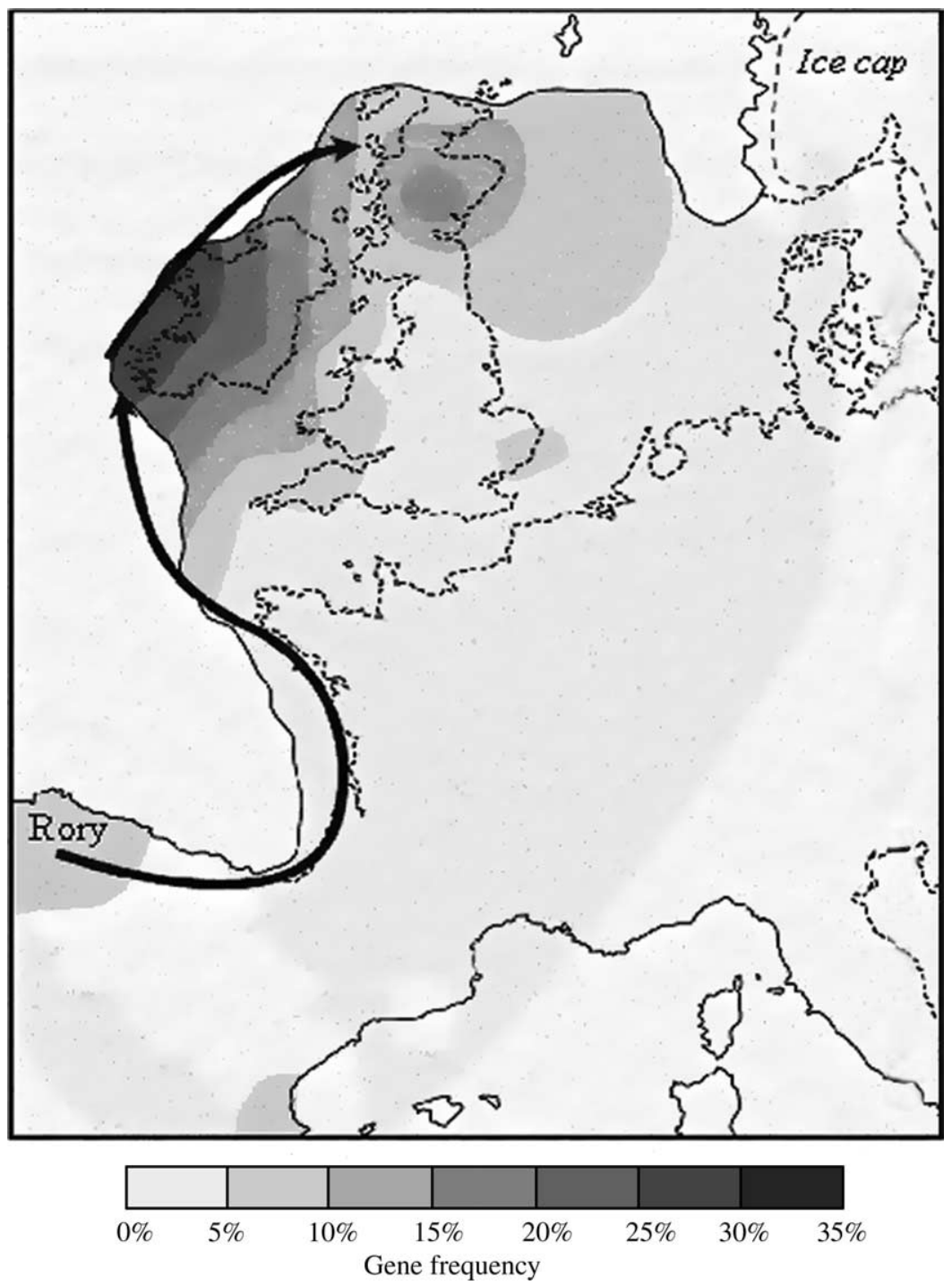

Fig. 4-Gene cluster R1b-14 ('Rory'). This map shows Rory, one of the larger early male clusters to re-expand from the south-west European refuge 15,000-13,000 years ago. Rory derives from 'Rox', also concentrating on the Atlantic façade, featuring particularly in Ireland and less so in Scotland. He is strongly associated with Irish men with Gaelic names-but this does not mean that Gaelic arrived so early! Compare with Fig. 2. Map and caption reproduced with permission from Oppenheimer (2006).

when all within the 100 fathom line was dry land allow the Asturian plants to reach Ireland \& if this happened when the emerald isle was nearly or quite separated from England it might explain why said southern species never got into England.

That type of map can be seen in Fig. 1, obtained from the General Bathymetric Chart of the Oceans, GEBCO Digital Atlas Centenary Edition (International Oceanographic Commission et al. 2003), the One Minute Grid of the International Oceanographic Commission.
Darwin did accept Forbes' hypothesis of a land connection between northern Spain and south-west Ireland and England, and considered likely Hennessy's hypothesis of human agency in the pattern of distribution of the Asturian plants (Burkhardt, in press):

Your view of their introduction through the agency of man is quite novel, but I suspect the botanists will object that the particular plants in question are unlikely kinds to have been thus introduced.-On the other hand those who most closely study Insular Floras seem to me to admit more \& more largely the 
introduction through man's agency of plants of many kinds.

Webb (1983) listed the plants constituting the "Irish Atlantic" botanical region and their corresponding European distribution (Fig. 2), with special mention of two Saxifraga-Saxifraga spathularis and Saxifraga hirsuta - that were already observed by Forbes, Hooker and Darwin in the 1850s. Pinguicula grandiflora, Erica mackaiana and Neotinea maculata are another three plants found in northern Spain and the south of Ireland, but not in Britain. Pollen and fossil studies (Coxon and Waldren 1995) suggest the continuous presence of these plants in situ from earlier periods, as well as their possible disappearance and recolonisation from southern refugia. Coxon and Waldren discuss the existence of numerous marine trading routes between Ireland and northern Spain in historical times that may be responsible for the introduction of taxa that are now local components of the modern Irish flora. Their absence in the intervening parts of England and France may simply imply that the climate and land type is presently wrong for them, but could have been favourable in the past, thus, allowing land spread.

Extensive data on the distribution of mitochondrial (maternally derived, see Fig. 3) and non-recombining Y-specific (paternally derived, see Fig. 4) human DNA in current Europeans suggest the existence of an ancient human population refuge in northern Spain at a time when the British Isles and northern Europe were covered by ice or by a vast polar sub-desert (Oppenheimer 2006). Such an enormous volume of seawater locked into ice produced a drop in global sea levels about $130 \mathrm{~m}$ below current levels. From this refuge, the population expanded northwards as soon as climatic conditions began to improve (about 15,000 years ago).

If in Fig. 1 we consider that nearly all the white area was at that time dry land, the south and west of Ireland would have been within relatively easier reach from northern Spain, compared to now. As Oppenheimer speculates, some of these earlier settlements may have occurred in lands now submerged. The Saxifraga issue suggests it is unlikely that human settlers moving northwards from their Iberian refuge were the only living organisms to follow such a path. Other 'footprints', such as those relating to the small group of Irish Atlantic plants, are likely to be found, having moved in the same direction already in the Miocene; or simultaneously with the withdrawal of the last ice cover, as Forbes and Darwin speculated; or later by human agency, as Hennessy speculated. Without the palynological or DNA data, the observations from 150 years ago could have had a bearing today.

\section{ACKNOWLEDGEMENTS}

This paper was written to mark the first 50 years of the Department of Genetics at Trinity College Dublin. I am grateful to the directors of the Correspondence of Charles Darwin Project at the University Library in Cambridge for providing access to the private digital database containing the unpublished letters transcribed in this paper. I am also grateful to the syndics of Cambridge University Library for permission to see unpublished documents and letters from the Darwin collection. Neither the Correspondence of Charles Darwin Project nor Cambridge University Library can be held responsible for any errors of transcription remaining. I am also grateful to Cambridge University Press for permission to transcribe text from Burkhardt et al. (1993). My thanks also to Professor Stephen Oppenheimer for helpful comments on an earlier version of the manuscript and for permission to reproduce Figs 3 and 4, which appeared in The origins of the British: a genetic detective story. Fig. 2 is reproduced by kind permission of the Royal Dublin Society.

\section{REFERENCES}

Anonymous 1848 On tar, as a preservative against the potato disease. Proceedings of the Royal Irish Academy 4, 119.

Anonymous 1852 A review of Francis B. Head's A fortnight in Ireland. The Dublin Review 34, 1-33.

Anonymous 1860 On the origin of species. The Dublin Review 48, 50-81.

Anonymous 1863 A commentary on the census of Ireland for 1861, 1851 and 1841. The Dublin Review 104, 279.

Anonymous 1864 Election of honorary members. Proceedings of the Royal Irish Academy 9, 389.

Anonymous 1874 British association for the advancement of science. London. The Times 21 August 1874.

Anonymous 1886 University intelligence. London. The Times 26 June 1886.

Attis, D. 1997 The social context of W.R. Hamilton's prediction of conical refraction. In P.J. Bowler and N. Whyte (eds), Science and society in Ireland: the social context of science and technology in Ireland 1800-1950. Belfast. Institute of Irish Studies, Queen's University Belfast.

Burkhardt, F. (in press) The correspondence of Charles Darwin. Volume 16: 1868. Cambridge. Cambridge University Press.

Burkhardt, F. and Smith, S. 1986 The correspondence of Charles Darwin. Volume 2: 1837-1843. Cambridge. Cambridge University Press.

Burkhardt, F. and Smith, S. 1987 The correspondence of Charles Darwin. Volume 3: 1844-1846. Cambridge. Cambridge University Press. 


\section{DARWIN'S IRISH CORRESPONDENCE}

Burkhardt, F. and Smith, S. 1988 The correspondence of Charles Darwin. Volume 4: 1847-1850. Cambridge. Cambridge University Press.

Burkhardt, F. and Smith, S. 1989 The correspondence of Charles Darwin. Volume 5: 1851-1855. Cambridge. Cambridge University Press.

Burkhardt, F. and Smith, S. 1990 The correspondence of Charles Darwin. Volume 6: 1856-1857. Cambridge. Cambridge University Press.

Burkhardt, F. and Smith, S. 1991 The correspondence of Charles Darwin. Volume 7: 1858-1859. Cambridge. Cambridge University Press.

Burkhardt, F. and Smith, S. 1994 A calendar of the correspondence of Charles Darwin, 1821-1882. Cambridge. Cambridge University Press.

Burkhardt, F., Browne, J., Porter, D.M. and Richmond, M. 1993 The correspondence of Charles Darwin. Volume 8: 1860. Cambridge. Cambridge University Press.

Burkhardt, F., Browne, J., Porter, D.M. and Richmond, M. 1994 The correspondence of Charles Darwin. Volume 9: 1861. Cambridge. Cambridge University Press.

Burkhardt, F., Harvey, J., Porter, D.M. and Topham, J.R. 1997 The correspondence of Charles Darwin. Volume 10: 1862. Cambridge. Cambridge University Press.

Burkhardt, F., Porter, D., Dean, S.A. and Topham, J.R. 1999 The correspondence of Charles Darwin. Volume 11: 1863. Cambridge. Cambridge University Press.

Burkhardt, F., Porter, D.M., Dean, S.A., White, P.S. and Wilmot, S. 2001 The correspondence of Charles Darwin. Volume 12: 1864. Cambridge. Cambridge University Press.

Burkhardt, F., Porter, D.M., Dean, S.A., Evans, S., Innes, S., Pearn, A.M., Sclater, A. and White, P. 2004 The correspondence of Charles Darwin. Volume 14: 1866. Cambridge. Cambridge University Press.

Coxon, P. and Waldren, S. 1995 The floristic record of Ireland's Pleistocene temperate stages. In R.C. Preece (ed.), Island Britain: a quaternary perspective, 243-67. London. Geological Society Special Publication No. 96.

Darwin, C. 1859 The origin of species, available at http://darwin-online.org.uk/ (22 February 2008).

Darwin, C. 1860 The origin of species, 2nd edn, available at http://darwin-online.org.uk/ (22 February 2008).

Darwin, C. 1861 The origin of species, 3rd edn, available at http://darwin-online.org.uk/ (22 February 2008).

Darwin, C. 1862 On the various contrivances by which British and foreign orchids are fertilised by insects, and on the good effects of intercrossing. London. John Murray.

Darwin, C. 1866 The origin of species, 4th edn, available at http://darwin-online.org.uk/ (22 February 2008).

Darwin, C. 1869 The origin of species, 5th edn, available at http://darwin-online.org.uk/ (22 February 2008).

Darwin, C. 1872 The origin of species, 6th edn, available at http://darwin-online.org.uk/ (22 February 2008).
Darwin, C. 1877 The various contrivances by which orchids are fertilised by insects, 2nd edn. London. John Murray.

Darwin, C. 1958 The autobiography of Charles Darwin 1809-1882. London. Collins.

DeArce, M. (in press) Correspondence of Charles Darwin on James Torbitt's project to breed blight resistant potatoes. Archives of natural history.

Encyclopædia Britannica 2007 Forbes, Edward, available at http://www.britannica.com/eb/article9034824 (11 May 2007).

Falconer, I. 2004 Hennessy, Henry (1826-1901), in Oxford Dictionary of National Biography, available at http://www.oxforddnb.com/view/article/33820 (22 February 2008).

Foster, J.W. 2002 Recoveries: neglected episodes in Irish cultural history 1860-1912. Dublin. University College Dublin Press.

Freke, H. 1860 On the origin of species by means of organic affinity. Dublin. Pantex and Co.

Haughton, S. 1860 Palaeontology II. Irish University Magazine 56, 20-34.

Hayes, R.J. 1970 Sources for the history of Irish civilisation: articles in Irish periodicals 6 (subjects: evolution). Boston. G.K. Hall \& Co.

Hennessy, H. 1870 On the origin of the South European plants found growing in the west and south of Ireland. Proceedings of the Royal Irish Academy 10, 66-70.

International Oceanographic Commission, International Hydrographic Organization and the British Oceanographic Data Centre 2003 Centenary edition of the GEBCO digital atlas. CD-ROM, available at http://www.ngdc.noaa.gov/mgg/ gebco (22 February 2008).

Jones G. 1998 Contested territories: Alfred Cort Haddon, progressive evolutionism, and Ireland. History of European Ideas 24 (3), 195-211.

Jones G. 2004 Darwinism in Ireland. In D. Attis and C. Mollan (eds), Science \& Irish Culture, vol. 1, 115-38. Dublin. The Royal Dublin Society.

Jukes, J.B. 1862 On the mode of formation of some of the river valleys in the south of Ireland. Journal of the Geological Society 18, 378-403.

Livingstone, D.N. 1997 Darwin in Belfast: the evolution debate. In J.W. Foster and H.G.C. Chesney (eds), Nature in Ireland, 387-408. Dublin. Liliput.

Mollan, R.C. 1987 Nostri plena laboris: an author index to the Royal Dublin Society scientific journals 1800 to 1985. Dublin. RDS Press.

Moore, D. 1860 On raising and growing seedlings potatoes; with some remarks on the origin and improvement of agriculture. Proceedings of the Royal Dublin Society 3 (17), 28-32.

Moore, D. 1870 Synopsis of the mosses of Ireland. Proceedings of the Royal Irish Academy 9, 329-474.

Moore, D. 1875 Design in the structure and fertilization in plants, a proof of the existence of God. In J.L. Porter (ed.), Science and revelation: a series of lectures in reply to the theories of Tyndall, Huxley, Darwin and Spencer etc. Belfast. Mullan.

Moore, D. 1876 Irish hepaticae. Proceedings of the Royal Irish Academy 12, 591-672. 


\section{Biology AND ENVIRONMENT}

Nelson, E.C. 1995 The cause of the calamity: potato blight in Ireland, 1845-1847, and the role of the National Botanic Gardens, Glasnevin. Dublin. Stationery Office.

Nelson, E.C. 2004 Harvey, William Henry (18111866), in Oxford Dictionary of National Biography, available at http://www.oxforddnb. com/view/article/12533 (24 October 2007).

Nelson, E.C. and Parnell, J. 2002 An annotated bibliography of the Irish botanist William Henry Harvey (1811-1866). Archives of natural history 29 (2), 213-44.

Nelson, E.C. and Seaward, M.R.D. 1980 Charles Darwin's correspondence with David Moore of Glasnevin on insectivorous plants and potatoes. Biological Journal of the Linnean Society 15, 157-64.

Oppenheimer, S. 2006 The origins of the British: a genetic detective story. London. Constable \& Robinson.
Peckham, M. 1959 The origin of species, a variorum text. Pennsylvania. University of Pennsylvania Press.

Roberts, N.K. 2007 Newman on the argument from design. New Blackfriars 88 (1013), 56-66.

Rosen, J. 2007 Missing link: Alfred Russel Wallace, Charles Darwin's neglected double. New York. The New Yorker Magazine 12 February 2007.

Spearman, T.D. 2004 Haughton, Samuel (18211897), in Oxford Dictionary of National Biography, available at http://www.oxforddnb. com/view/article/12616 (8 November 2007).

University of Cambridge 2007 Darwin Correspondence Project, available at http://www.darwinproject.ac. uk/ (15 May 2007).

Webb, A. 1983 The flora of Ireland in its European context. Journal of Life Sciences of the Royal Dublin Society 4, 143-60. 